\title{
CCL3 wt Allele
}

National Cancer Institute

\section{Source}

National Cancer Institute. CCL3 wt Allele. NCI Thesaurus. Code C49746.

Human CCL3 wild-type allele is located within 17q11-q21 and is approximately $2 \mathrm{~kb}$ in length. This allele, which encodes C-C motif chemokine 3 protein, is involved in the acute inflammatory recruitment and activation of polymorphonuclear leukocytes. 